\title{
Risk-oriented approach to long-term sustainability management for oil and gas companies in the course of implementation of investment projects
}

\author{
A. Domnikov, G. Chebotareva, P. Khomenko \& M. Khodorovsky \\ Academic Department of Banking and Investment Management, \\ Ural Federal University named after the first President of Russia B.N. \\ Yeltsin, Russia
}

\begin{abstract}
Under conditions of the economic and technology-related risks growing in the contemporary society, the availability of an efficient risk management system represents a crucial factor of business competitiveness and rate of return. This paper presents a proprietary approach to risk management for oil and gas companies in the implementation of investment projects. A rating model for investment project risk assessment considering the numerosity of factors is presented. A method for economic capital assessment based on the MertonVasicek model was developed which allows establishing the operating targets for long-term sustainability management for oil and gas companies under conditions of investment risk. Practical aspects of the risk assessment and management for oil and gas business are considered, as applied to a company playing in the sector. The results of the study may be used by the management of oil and gas companies, investors and analysts in the course of financial decision-making.

Keywords: long-term sustainability, oil and gas company, investment project, investment risks, probability of default, logit model, Merton-Vasicek method.
\end{abstract}

\section{Introduction}

Attraction of private investments in oil and gas companies is currently one of the priority lines of the sector development. The required amount of raised capital 
allows not only upgrading the existing technology but also setting up up-to-date objects in accordance with investment projects under implementation.

However, for potential investors, along with the yield and payback period, there is an undated question: how sustainable is this oil and gas company, what are its development outlooks, and what specific risks the investment project will run.

Therefore, we see an emerging complicated problem consisting not only in the study into latent risks run by the oil and gas company, but also in the analysis of the company's long-term financial sustainability in the realisation of multidirectional investment projects, taking into account the probability of default and volatility of mineral commodity markets.

The undertaken study resulted in the developed proprietary approach to the assessment of oil and gas company's economic capital, which allows the online identification of the most critical points in the implementation of respective investment projects and the development of corporate long-term financial sustainability management program.

\section{Development of long-term sustainability for oil and gas companies}

The current economic literature gives a variety of definitions for long-term sustainability of a company. Within the framework of this study, defining its principal development vector, the long-term financial sustainability of an oil and gas company should be deemed the business ability to ensure the continuity of performance, stability of revenue generation with continued capability of cost optimisation and high level of innovation activity considering sustainable competitive edges, unique market position and destabilising environmental exposure.

The basic factors affecting the development of long-term financial sustainability of and oil and gas companies were listed above. Nevertheless, the modern risk-oriented approach to the assessment of corporate sustainability defines a number of additional factors, such as: level of assumed risk within implementation of a specific investment project undertaken by an oil and gas company, related probability of the project default, as well as the company's ability to cover the default losses, i.e. the amount of economic capital (Domnikov et al. [1]).

\subsection{The role of economic risk management in industrial development}

The internal and external environment of the industrial company, are as a sources of opportunities for the realization of competitive advantages and as a sources of hazards for industrial development. Economic impacts from the implementation risks can be the following:

1. Direct losses associated with material damage inflicted company (losses of resources, fixed assets, intangible assets);

2. Deficiency the planned profit, cash flow due to the reduction of income, excess spending growth, loss of benefit, the use of investment alternatives. 
Due to the complexity of the technological environment, economic and financial relations, the growing of uncertainty risk factors the main problem of risk management in industrial development take on special significance for long-term business planning and strategy implementation.

The variety of risks that track the development of industrial companies, includes the several economic risks. Quality of the risk-management defines:

1. The continuity of supply, which is the main condition for the regular industrial production;

2. The stability of production sales and operating cash flow of the business;

3. The efficiency of investment activity, adherence to which is achieved by the proper selection of investment projects and business portfolio of the company;

4. Business supporting of the necessary financial resources for current operations, capital programs, maintain technological level and modernization of production capacities.

In this regard, sustainable industrial development is impossible without the effective mechanism for the identification, evaluation and management of economic risks.

\subsection{Specifics of investment risks run by oil and gas companies as an assessment factor for long-term financial sustainability}

Within the framework of this study, twelve principal risks were considered including those of latent nature, which emerge during implementation of investment projects undertaken by oil and gas companies.

All specific risks are divided into two groups according to the level of impact on the oil and gas company: exogenous risks and endogenous risks (Domnikov et al. [2]). Below is given a brief characterisation of each of the groups.

The exogenous risks are independent of operations conducted by the oil and gas company and are beyond its control. In this study, the following risks are considered as such:

- Risk of "state attractiveness" characterised by the investment climate of a country where the company is operating $\left(\mathrm{X}_{1}\right)$;

- Risk of "regional attractiveness" characterised by the investment climate and developmental trends of a region where the company's investment project is being implemented $\left(\mathrm{X}_{2}\right)$;

- Mineral resource-related risk: global trends in the overall sector development considering the volatility of mineral commodity market $\left(\mathrm{X}_{3}\right)$;

- Government support-related risk: pursuit by a government in the country where the company is situated to make public investments, guarantee a certain level of return on private investments $\left(\mathrm{X}_{4}\right)$;

- Currency-related risk characterised by a potential losses for the company as a result of adverse changes in the foreign exchange rates $\left(\mathrm{X}_{5}\right)$.

The endogenous risks are the outcome of assessment and analysis into all spheres of operations and financial activities undertaken by the oil and gas company. The following risks are considered as such: 
- “Operating" risk: general deterioration of company's financial standing as a result of inefficient operating activities $\left(\mathrm{X}_{6}\right)$;

- Investment project-related risk: risk of increase in the company's financial losses related to the implementation of investment projects $\left(\mathrm{X}_{7}\right)$;

- Investment risk: risk of general deterioration of company's financial standing as a result of inefficient miscellaneous investment activities $\left(\mathrm{X}_{8}\right)$;

- Underfunding risk: risk related to the investment project cost growth $\left(\mathrm{X}_{9}\right)$;

- Risk of contingent financial losses which are difficult to forecast and of a latent nature $\left(\mathrm{X}_{10}\right)$;

- Environmental risk characterised by excessive industrial emissions to the environment $\left(\mathrm{X}_{11}\right)$;

- Technology-related risk: plant and equipment renewal rate $\left(\mathrm{X}_{12}\right)$.

The practical assessment and analysis of each of the presented risks are given in Section 5 of this article.

\section{Rating model for assessment of investment projects}

General methodology for the assessment of long-term sustainability of investment projects based on the calculation of the company's economic capital was presented by the authors in a number of works (Domnikov et al. [1]). One of the components in this approach is a calculation of default probability for analysed investment projects using the logit model (Merton [3]). Specifics of the logit model are described in paragraph 3.1 .

\subsection{Specifics of the rating model for assessment of investment projects}

Within the management of long-term financial sustainability for oil and gas companies, the assessment of emerging investment risks run by the projects offered for implementation is made by using a logit model. This involves a logistic transformation applied to the forecasting, based on the maximum likelihood (ML) method (Vasicek [4]).

General form of the logit model is given in eqn (1) (Vasicek [4]):

$$
P D=\left(y_{i}=1\right)=\frac{1}{1+e^{-z}}
$$

where PD - the investment project default probability; $\left(y_{i}=1\right)$ - the case where the investment projects becomes in default; $z=\left(b_{0}+b_{1} * X_{i 1}+b_{2} * X_{i 2}+\cdots+\right.$ $\left.b_{n} * X_{i n}\right) ; X_{i j}-$ the value of financial indicator $j$ for investment project $i ; b_{j}$ - the estimated significance of factor $j$.

The basis for the logit model is data characterising the borrower's financial activity. As a rule, the logit model includes at least ten financial variables for analysis: equity to debt ratio, return on total assets, net earnings index, dummy variable characterising the sign of net earnings for the previous two years, etc. (Ohlson [5]).

Apart from the basic financial indicators, the logit model considers the combination of exogenous factors (investment climate in the country and region, 
level of sector governmental support etc.), which play a key role in the process of financial decision-making by the investor.

The use of the logit model results in the ultimate ranking of investment projects according to the default probability.

\subsection{Application of rating model to the assessment of investment projects undertaken by oil and gas companies}

The model includes twelve risks described above; each of them has its own particular features within each of the investment projects of interest.

Given the difficulties in acquisition of statistical information on default probabilities for similar investment projects, this study made use of the expert assessment method. A questionnaire poll was conducted among heads of departments and divisional superintendents of an oil and gas company in Russia with respect to the assessment of presented risks according to the specified scale (Domnikov et al. [6]).

This assessment resulted in the specification of a logit model for the oil and gas company, applicable to each project $i$. The refined $z$ parameter in eqn (1) will assume the following form, such as eqn (2):

$$
\begin{array}{r}
z=0.5578+1.0012 * X_{i 1}+0.8794 * X_{i 2}+0.1478 * X_{i 3}+0.9841 * X_{i 4}+ \\
0.5878 * X_{i 5}+0.6587 * X_{i 6}+1.0231 * X_{i 7}+0.1495 * X_{i 8}+1.0488 * X_{i 9}+ \\
0.8974 * X_{i 10}+0.2358 * X_{i 11}+0.9875 * X_{i 12}
\end{array}
$$

\section{Basic components of capital risk model}

The key parameters characterising an investment project for the purposes of assessing the economic capital are the following (Domnikov et al. [1], Gorby [7], Merton [3], Ohlson [5], Vasicek [4]):

$P D$ - probability of default. A key indicator characterising the project risk level and reflecting the potential probability of the investment project default.

$L G D$ - loss given default. Expected average relative losses to be incurred by the company in case of the investment project default. In case of default this portion of the investment project cost will be lost irrecoverably. The reason for introducing this indicator is that in the event of investment project default the project may be realised in full or in part by means of sale, insurance and option claims, etc.

$E A D$ - exposure at default. This characterises an absolute value of the investment project and is determined by the project's full actual or forecast capital, current and other costs.

$M$ - maturity. An average period during which the risk maintains its position. This is determined by the project investment phase duration. Prolonged investment phase will lead to growth of risks due to increased uncertainty of the implementation results. Shortened investment phase will lower the overall project risk.

The PD assessment model as a component of capital risk was described above. The economic capital is calculated considering the probability of investment project default. 
The PD parameter is assessed in 4 steps:

1. Data pre-processing for modelling is made based on the implementation statistics for the company's investment projects over the durable period (at least 3 years). The key parameters for assessment may be the LGD for each defaulting project or the RR (recovery rate) characterising the percentage of the project cost, which was recovered as a cash flow following the project default.

2. Classification of investment projects by the criterion of LGD difference significance. Clustering of investment projects may be based on the criteria of scale, objectives, effect types, implementation periods, cash flow types, state of economy and other criteria. The final clustering shall be based on the criterion of significance of average differences in the sample, which may be estimated using the Student t-test, Fischer F-test, Kolmogorov-Smirnov test, Mann-Whitney U-test (Gmurman [8]).

3. Formulating the LGD distribution for each cluster. Based on the LGD statistical data the distribution for each classification group is formulated.

4. Estimation of LGD distribution form and determination of key parameters. At this step the distribution form is estimated and parameters for LGD modelling in each classification group are determined. The distribution form may be estimated using the chi square test, Anderson-Darling test, Kolmogorov-Smirnov test (Gmurman [8]).

From henceforth, when modelling the economic capital by Merton-Vasicek model the LGD numeric values will be used, however, for calculation of capital risk by simulation modelling method, LGD may be used as a random variable with parameters specified in Section 4.

The maturity characterises the penalty on the prolonged investment phase. Additional adjustment for the capital risk for the project duration more than 1 year is made using eqn (3) (Vasicek [4]):

$$
M=\frac{1+T-2.5 * b(P D)}{1-1.5 * b(P D)},
$$

where $\mathrm{M}$ - the maturity, $\mathrm{T}$ - the investment project risk horizon, $\mathrm{b}(\mathrm{PD})=0.00852-0.05489 \times \ln (\mathrm{PD})$.

Shift and slope parameters for the maturity may be estimated by the company itself for different types of investment projects, based on the statistical data. Also, the model may be adjusted taking into account the investment project average duration (Gurtler and Heithecker [9]).

Also, the concentration factor for the company's investment projects may be considered a penalty, however, the concentration modelling is beyond this study.

\section{Application of economic capital assessment model for an oil and gas company}

Supposing that the investment program of an oil company includes 5 investment projects with the source parameters as given in Table 1 . 
Table 1: Key parameters of investment project under implementation.

\begin{tabular}{|c|l|c|c|c|}
\hline № & \multicolumn{1}{|c|}{ Projects } & $\begin{array}{c}\text { Full cost, } \\
\text { \$ million }\end{array}$ & $\begin{array}{c}\text { Project } \\
\text { implementation } \\
\text { period, years }\end{array}$ & $\begin{array}{c}\text { Probability of } \\
\text { default, \% }\end{array}$ \\
\hline 1 & Replacement of cold water pump & 10 & 0.3 & 3.5 \\
\hline 2 & Upgrading of main oil pipeline & 45 & 2 & 8.1 \\
\hline 3 & Oil storage construction & 35 & 2 & 8.5 \\
\hline 4 & $\begin{array}{l}\text { Upgrading of oil refining department } \\
\text { at Refinery No 1 }\end{array}$ & 120 & 4 & 5.5 \\
\hline 5 & Upgrading of petrol station chain & 30 & 2 & 5.4 \\
\hline
\end{tabular}

Given the requirement to manage the long-term sustainability of oil and gas assets, determination of the financial sustainability strategic level, which is the long-run target, is the important stage of risk management. This level of financial sustainability may be determined using a target long-term credit rating the company is seeking to obtain. The company value and development strategy becomes an important factor in the risk assessment and management. Each credit rating may be assigned a certain level of $\mathrm{PD}$, depending on the forecasting horizon. One of the matching options for credit rating and probability of default is given in Table 2 (Domnikov et al. [10], Khodorovsky et al. [11]).

Table 2: Correspondence between the probability of default and credit rating.

\begin{tabular}{|l|c|c|c|}
\hline Rating & $1-Y$ PD & $3-Y$ PD & $5-Y$ PD \\
\hline AAA & $0.008 \%$ & $0.03 \%$ & $0.1 \%$ \\
\hline AA & $0.04 \%$ & $0.16 \%$ & $0.28 \%$ \\
\hline A & $0.16 \%$ & $0.4 \%$ & $0.58 \%$ \\
\hline BBB & $0.3 \%$ & $1.4 \%$ & $3 \%$ \\
\hline BB & $1.15 \%$ & $8.6 \%$ & $15 \%$ \\
\hline B & $5.8 \%$ & $15.4 \%$ & $32.6 \%$ \\
\hline CCC or lower & $26.57 \%$ & $45.5 \%$ & $60 \%$ \\
\hline
\end{tabular}

The probability of default determines the level of confidence required to calculate the contingent losses and economic capital of an oil and gas company, which is calculated using eqn (4):

$$
\gamma=1-P D,
$$

where $\gamma$ is the confidence level determining the probability of smash up nonoccurrence; PD is the probability of default corresponding to the target credit rating.

Based on the LGD distributions, an estimate of statistically distinctive LGD basic parameters for each type of investment projects was obtained. The distribution is presented in Fig. 1 and Table 3. 

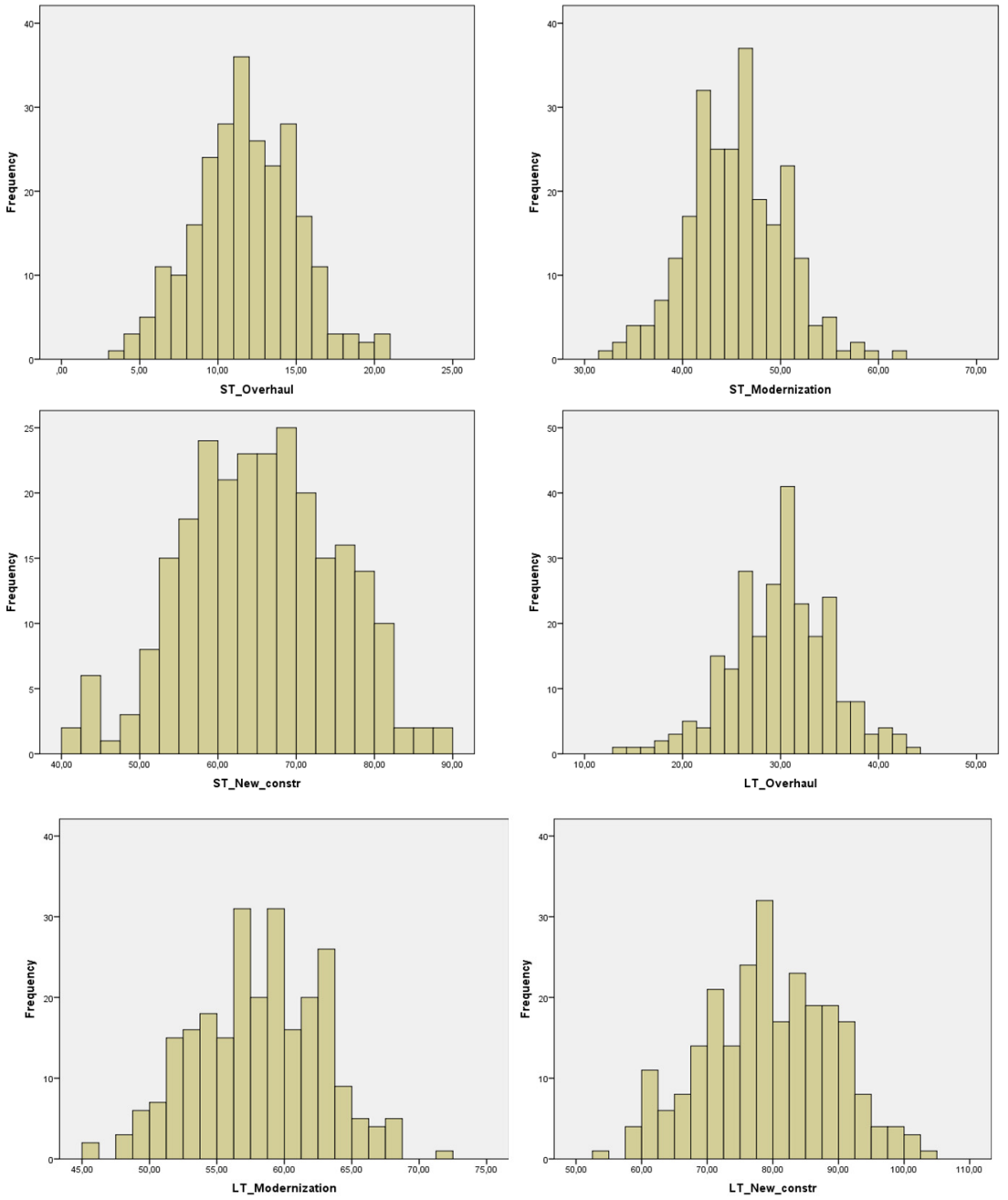

Figure 1: LGD distribution for main types of investment projects.

Table 3: $\quad$ LGD estimates for main types of investment projects.

\begin{tabular}{|c|c|c|c|}
\hline $\begin{array}{c}\text { Project duration/ } \\
\text { Project type }\end{array}$ & Overhaul & Upgrading & New construction \\
\hline Short-term & $12 \%$ & $45 \%$ & $65 \%$ \\
\hline Long-term & $30 \%$ & $58 \%$ & $80 \%$ \\
\hline
\end{tabular}

The Merton-Vasicek model (Merton [3], Vasicek [4]) was used as a method for estimating the economic capital. The correlation coefficient between the project indicators and macro indicators, which allows separating the idiosyncratic 
risk from the systematic risk, is estimated individually for each of the project type. In this model the reliability parameter is specified at a level of $99.97 \%$ which corresponds to the target credit rating BBB. The company's economic capital is calculated using eqn (5) (Domnikov et al. [1]):

$$
C a R=E A D * L G D *\left(N *\left(\frac{N^{-1}(P D)+\sqrt{R} * N^{-1}(\alpha)}{\sqrt{1-R}}\right)-P D\right),
$$

where CaR - company's capital risk; $\mathrm{N}$ - standard normal distribution function; $\mathrm{R}$ - coefficient of correlation between the project (company) indicators and the overall state of economy; $\alpha-$ level of reliability.

The calculation of capital risk required to attain sustainability corresponding to $A A A, B B B, B B$ ratings is presented in Table 4.

Table 4: Calculation of capital risk for different levels of financial sustainability.

\begin{tabular}{|l|l|l|l|l|l|l|l|l|}
\hline Project & $E A D$ & $T$ & $P D$ & $L G D$ & $R$ & $C_{A} R_{A A A}$ & $C_{a R_{B B B}}$ & $C a R_{B B}$ \\
\hline $\begin{array}{l}\text { Replacement of cold } \\
\text { water pump }\end{array}$ & 10 & 0.3 & 0.035 & 0.12 & 0.1 & 0.19 & 0.15 & 0.03 \\
\hline $\begin{array}{l}\text { Upgrading of main oil } \\
\text { pipeline }\end{array}$ & 45 & 2 & 0.081 & 0.58 & 0.25 & 12.11 & 10.26 & 3.43 \\
\hline $\begin{array}{l}\text { Oil storage } \\
\text { construction }\end{array}$ & 35 & 2 & 0.085 & 0.65 & 0.2 & 9.97 & 8.46 & 3.31 \\
\hline $\begin{array}{l}\text { Upgrading of oil } \\
\text { refining department at } \\
\text { Refinery No 1 }\end{array}$ & 120 & 4 & 0.055 & 0.58 & 0.55 & 28.77 & 25.82 & 0.15 \\
\hline $\begin{array}{l}\text { Upgrading of petrol } \\
\text { station chain }\end{array}$ & 30 & 2 & 0.054 & 0.58 & 0.62 & 6.38 & 5.95 & -0.06 \\
\hline Total: & & & & & & 57.41 & 50.64 & 6.85 \\
\hline
\end{tabular}

The calculations have shown that the higher is the target corporate credit rating, the higher requirements to capital are set by the model. Thus, to match AAA credit rating, the capital required to cover the losses from the implementation of investment projects is $\$ 57.41 \mathrm{~m}$, to match $\mathrm{BBB}$ rating, $\$ 50.64 \mathrm{~m}$, and to match BB rating, $\$ 6.85$ million (Peter [12]).

\section{Conclusions}

The business competitive position largely depends on its ability to perform in sustainable manner and to generate cash flows. In this aspect, the key issue is the risk management problem, the solution of which is a pre-requisite for ensuring the long-term sustainability of companies. This problem acquires a special significance under conditions of implementing the investment projects, which may either enhance the business efficiency and scale or lead the company to collapse. The capital management model which is widely used and commonly recognised in risk management is the basis for the approach offered by the authors to the risk management for oil and gas companies. A model for project default probability assessment was developed based on the rating system; a method is offered for 
estimation of capital risk key components, i.e. losses given default, exposure at default and maturity.

The methodological approach to the assessment of investment portfolio risks based on the Merton-Vasicek model proves effective and simple in application, however, a number of lines for modelling capital risk are promising. In particular, it is necessary to develop an approach to estimate the correlation between the investment projects and the overall state of economy, which implicates the formulation of a multi-factor indicator allowing the global trends and their impact on investment activity to be identified. Also, an important problem consists in the refining of EAD model, which considers the project cost distribution at defaulting. Solution of the said problems will allow ensuring the sustainable development of business under conditions of uncertainty and risk.

\section{References}

[1] Domnikov, A., Khomenko, P. \& Chebotareva, G., A risk-oriented approach to capital management at a power generation company in Russia. WIT Transactions on Ecology and the Environment, 1, pp. 13-24, 2014.

[2] Domnikov, A., Chebotareva, G. \& Khodorovsky, M., Evaluation of investor attractiveness of power-generating companies: special reference to the development risks of the electric power industry. WIT Transactions on Ecology and the Environment, 1, pp. 199-210, 2014.

[3] Merton, R.C., On the pricing of Corporate debt: The risk structure of interest rates. Journal of Finance, 29, pp. 449-470, 1974.

[4] Vasicek, O., Loan portfolio value. Credit portfolio models, 15, pp. 160-162, 2002.

[5] Ohlson, J.A., Financial Ratios and the Probabilistic Prediction of Bankruptcy. Journal of Accounting Research, 18(1), pp. 109-131, 2012.

[6] Domnikov, A., Chebotareva, G. \& Khodorovsky, M., Systematic approach to diagnosis lending risks in project finance. Audit and Finance analyses, 2, pp. 114-119, 2013.

[7] Gorby, M.B., A risk-factor model foundation for rating-based bank capital rules. Journal of Financial Intermediation, 25, pp. 199-232, 2003.

[8] Gmurman, V., Probability theory and mathematical statistics. Higher School, 1, p. 479, 1997.

[9] Gurtler, M. \& Heithecker, D., Multi-Period defaults and maturity effects on economic capital in a ratings-based default-mode model. Finanz Wirtschaft, 5, pp. 123-134, 2005.

[10] Domnikov, A., Khodorovsky, M., \& Khomenko, P., Optimization of finances into regional energy. Economy of region, 2, pp. 248-253, 2014.

[11] Khodorovsky, M., Domnikov, A. \& Khomenko, P., Optimization of financing investments in a power-generation company. WIT Transactions on Ecology and the Environment, 1, pp. 45-54, 2014.

[12] Peter, C., Estimating Loss Given Default - Experiences from Banking Practise. Springerlink, 2, pp. 143-175, 2006. 